\title{
Impact of RTE Act on Girl Child Education
}

\author{
Sonal Mobar, Member, IEDRC
}

\begin{abstract}
Under Right to Education Act (RTE), the government provides Kasturba Gandhi Balika Vidayalyas (KGBV) which are residential schools in educationally backward blocks at upper primary level for girls belonging predominantly to the Scheduled Castes, Scheduled Tribes, Other Backward Class and minority communities. According to the MHRD (2011), KGBVs are set up in educationally backward blocks, where the female rural literacy is below the national average (i.e. below $46.13 \%$ as per Census 2001) and gender gap in literacy is above the national average of $21.67 \%$. This paper explores the conditions of KGBVs, the impact of RTE on girl enrolment and retention. The author explores the challenges and opportunities faced by girls, hindrances in their education and the impact of RTE in providing access of education to them. Overall, the paper explores the dimensions of gender, equity and quality under RTE and suggests measures to be taken up at policy level itself.
\end{abstract}

Index Terms -Equity, girl education, literacy, RTE, rights.

\section{INTRODUCTION}

Bridging the gender and social gaps in elementary education is one of the fundamental goals of Sarva Shiksha Abhiyan (SSA). It is a comprehensive and integrated flagship program of government of India, launched in 2000-01, to attain Universal Elementary Education in the country in a mission mode. The role of Universal Elementary Education (UEE) is strengthening the social fabric of democracy through provision of equal opportunities to all. Currently, Sarva Shiksha Abhiyan (SSA) is implemented as India's main programme for universalizing elementary education. Its overall goals include universal access and retention, bridging of gender and social category gaps in education and enhancement of learning levels of children. Sarva Shiksha Abhiyan or 'Education for All' programme recognizes that ensuring girl's education requires changes not only in the education system but also in societal norms and attitudes. A two-pronged gender strategy has therefore been adopted, to make the education system responsive to the needs of the girls through targeted interventions which serve as a pull factor to enhance access and retention of girls in schools and on the other hand, to generate a community demand for girls' education through training and mobilization.

Under SSA, the whole attempt is to reach out to children who are excluded from the benefits of education. Among these, the girls are considered the hardest to reach out to. As per cultural practices, girls are supposed to do household

Manuscript received June 10, 2014; revised August 13, 2014.

Sonal Mobar is with the Center for Equity and Social Development, National Institute of Rural Development, Hyderabad (Andhra Pradesh) 500030, India (e-mail: smobar2@gmail.com). chores which include collecting firewood, preparing meals, grinding spices, washing and drying clothes, looking after the young siblings, etc. As per SSA framework, SSA's focus is on gender parity which is rooted in the National Policy on Education which brought center-stage the issue of gender and girl's education.

\section{SSA AND RTE}

The $83^{\text {rd }}$ Constitutional Amendment recognizes the right to free and compulsory education as fundamental and therefore a justiciable right for the children between 6-14 years. The Act lays down that each child should be imparted education in such a manner that frees from fear, trauma and anxiety and is able to convey his views clearly [1]. The Right to Education (RTE) Act strives for effective and transformative education. This falls under the domain of universal human right, which leads to entitlement to claim the substance of it; it relates to the possibility of demanding the right to education and making it justiciable. Tomasevski (1999) interprets the norms in RTE and summarizes them in a 4-A scheme. The 4-A scheme stands for availability, accessibility, acceptability and adoptability [2].

The Right of children to free and compulsory education Act came into force from April 1, 2010. The RTE Act has 37 sections, seven chapters and one schedule which clearly lay down the aims and goals of the Act. Some of the salient features of the RTE Act, 2009 include that every child in the age group of 6-14 years will be provided 8 years of elementary education in an age appropriate classroom in the vicinity of his/her neighbourhood, providing free and compulsory education. It provides for a non-admitted child to be admitted to an appropriate class. The Act also mentions about norms and standards, the Pupil-Teacher Ratio, the buildings and infrastructure etc. No child shall be denied admission for want of documents; no child shall be turned away if the admission cycle in the school is over and no child shall be asked to take an admission test. Children with disabilities will also be educated in the mainstream schools. 100 percent enrolment is ensured by providing a Primary School with in $1 \mathrm{~km}$ radius and Upper Primary School in 3 $\mathrm{km}$ radius of all the habitations. It has also to ensure that child belonging to weaker sections and disadvantaged groups are not discriminated against and prevented from pursuing and completing elementary education on any grounds. The teachers should not be engaged in any other activities apart from teaching. It must also ensure and monitor admission, attendance and completion of elementary education by every child and that the quality of elementary education conforms to the standards and norms specified in the schedule. Looking at the census records, we can see that female literacy has gone up from $8.86 \%$ in 1951 to $53.67 \%$ in 2001 as shown 
in Table I. Though it is an upward gradient, the final milestone is quite far.

TABLE I: STATUS OF FEMALE EDUCATION IN INDIA

\begin{tabular}{|c|c|c|c|}
\hline $\begin{array}{c}\text { CENSUS } \\
\text { YEAR }\end{array}$ & PERSONS & MALE & FEMALE \\
\hline 1951 & 18.33 & 27.16 & 8.86 \\
\hline 1961 & 28.30 & 40.40 & 15.35 \\
\hline 1971 & 34.45 & 45.96 & 21.97 \\
\hline 1981 & 43.57 & 56.38 & 29.76 \\
\hline 1991 & 52.21 & 64.13 & 39.29 \\
\hline 2001 & 64.84 & 75.26 & 53.67 \\
\hline
\end{tabular}

(2001 Census)

\section{GIRL CHILD EDUCATION IN INDIA}

The Indian government has expressed a strong commitment towards education to all. However, India still has one of the lowest female literacy rates in Asia. The low rates of female literacy not only have a negative impact on women's lives but also the country's economy as well [3]. Numerous studies show that illiterate women have high rates of maternal mortality, poor nutritional status, low earning potential and little or no autonomy within their household. Lack of an educated population can be an impediment to the country's economic development. Since the governments have realized this, they have developed many schemes to educate the females of the country. There have been programs and policies to check negative teacher attitudes, biases in curriculum, lack of female teachers and inadequate hygiene and sanitation conditions in schools that inhibit girl child enrolment and retention [4].

\section{EQUITY LEADS TO EQUALITY}

By equity we mean equal rights that are justifiable. It is seen that there are cultural and societal practices that lead to stereotyping roles and responsibilities of girls. These in turn lead to bringing a skewed role-play in genders. It is required that teachers and parents be sensitized to handle gender-related differences. It is generally observed that in classrooms, where both girls and boys are present, the teachers tend to give more attention towards boys. Girls are seen sitting passively. This affects students' participations in classrooms. There are certain unsaid rules that are born in such classrooms and carried with young minds all throughout their life.

It is often seen that language reinforces gender stereotypes in most places. The masculinity is described in certain terms that affirm strength and aggression and femininity in such terms that are docile and submissive in character. There are pictures in textbooks which reaffirm these ideas on the impressionable young minds. Visibility of women is very low as compared to men's appearance in the textbooks. Women and men are identified with stereotypical attributes: brave, heroic, honest, are portrayed as male; and caring, self scarifying, love and kindness as female attributes. Under-representation of women is clearly evident in all the textbooks across subjects. Little effort is made to depict women in non-traditional roles and portray them as capable of making choices. Issues of quality and equity are inextricably linked. Education processes to be transformative in terms of preparing students to question existing gender relations and notions of masculinities and being feminine. School is a place where students have opportunities for questioning, debating, seeing new perspectives, forming new identities and relations without feeling threatened or weak. Gender disparities persist strongly in rural areas and among disadvantaged communities. Therefore a critical aspect of promoting gender equality is the empowerment of women, with a focus on identifying and redressing power imbalances and giving women more autonomy to manage their own lives. Education is one such tool that empowers them. And this right to education for girls can be achieved efficiently if measures to resolve related issues such as exploitative and discriminatory behavior, sexual abuse and physical violence are laid stress on [5]. Efforts have to be made to increase the enrolment and attendance of girls in schools and there is need to address the deep-seated cultural norms and values that impede girls' access to education [6].

\section{OBJECTIVES}

The main objective of this paper is to explore the status of girl child education with reference to Kasturba Gandhi Balika Vidayalays. Apart from that, the paper will discuss the quality and equity issues related to girl child education, the challenges and opportunities they face in accessing education and the overall impact of RTE in enrolment and retention.

\section{KASTURBA GANDHI BALIKA Vidyalaya (KGBV)}

The Kasturba Gandhi Balika Vidyalaya scheme is merged with Sarva Shiksha Abhiyan in the XIth Plan with effect from $1^{\text {st }}$ April, 2007. KGBV is a scheme launched in July 2004, for setting up residential schools at upper primary level for girls belonging predominantly to the Scheduled Caste (SC), Scheduled Tribe (ST), Other Backward Classes (OBC) and minority communities. The scheme is being implemented in educationally backward blocks of the country where the female rural literacy is below the national average and gender gap in literacy is above the national average. The scheme provides for a minimum reservation of $75 \%$ of the seats for girls belonging to SC, ST, OBC or minority communities and priority for the remaining $25 \%$, is accorded to girls from families below poverty line.

Till date, the government of India has sanctioned 2578 KGBVs. Of these, $427 \mathrm{KGBVs}$ have been sanctioned in Muslim concentration blocks, 612 in ST blocks, and 688 in SC blocks. As on $31^{\text {st }}$ January, 2009, 2423 KGBVs are reported to be functional (i.e. 94\%) in the States and 1,90,404 girls enrolled in them. Out of the total 2578 sanctioned KGBVs, 547 KGBVs have been constructed +1262 are in progress and 769 have not been started. The objective of $\mathrm{KGBV}$ is to ensure access and quality education to the girls 
of disadvantaged groups of society by setting up residential schools with boarding facilities at elementary level. Approx. Rs.20 lakhs for each KGBV (100 girls) is sanctioned. The main aim of this programme/ scheme is to mainstream the backward girls in school, to increase the quality education of girls to create girls friendly environment in schools, and to create awareness among the community members for girls education.

Along with studies, vocational training is provided to the residents of KGBV so that after completion of education in the school they can be self dependant. For a smooth functioning of KGBV there is a need to build the capacity of the students and staff. Faculties from different subjects are involved to train staff members in capacity building. A popular cartoon character 'Meena' is used to spread the message of girl education. It has succeeded in increasing the girls' enrolment in many villages. Girls are sensitized on social issues and the challenges they might face later in life. At KGBVs, girls are engaged in various arts and crafts activities from basket making, weaving, pottery, ceramic work, embroidery, crochet, etc. Through learning all these interesting things, they become very skillful. Interested girls are given coaching and trainings in archery, tennis, etc. too. They are also engaged in other recreational activities also such as folk games, sports, essay and story writing, puppet making, rangoli making, mehandi, painting, collage making, dance and drama, etc. Every month parent-teacher meetings are organized where parents are informed about the school resources, about the activities held in the school and progress of their ward. They are also asked to give their views and suggestions. The inmates of KGBVs are given all due entitlements on time such as books, uniforms, bags, etc. and cosmetic charges of Rs.50 per month. There are cooks, wardens, and guards to look after the KGBV center. It is observed that KGBV are generally well-maintained with classrooms, properly ventilated dormitories, library, entertainment room, kitchen, Head-mistress room, etc. Sanitation and hygiene is well-maintained. There are facilities of playgrounds too. A kitchen-garden is maintained with the help of girls. Products grown there are used in cooking at the KGBV. Good thoughts and moral values are also inculcated in girls to make them grow as a better human being.

\section{Challenges AND OPPORTUNITIES}

Girl child education is affected by many issues such as poverty, social values, inadequate school facilities, shortage of female teachers, and gender bias in curriculum. Access to education has been one of the most pressing demands of the women's rights movements. They have to face challenges and hindrances from familial to societal levels. Firstly, they are not sent to schools as they are deployed in household chores. In case they are enrolled in schools, there are various issues related access, transport, safety and quality. Some parents fear to send their daughters to schools because the way to schools is not safe. The girls might have to cross highways, bridges, railway tracks, forests, etc. and if there is no escort, it is not safe for the girls. This leads to girls being drop-outs or out of school. Secondly, infrastructural facilities at schools might pose a de-motivator. Inadequate toilet facilities force the girls to go in the open fields to urinate/defecate. Thirdly, inadequate female staff is also a problem. Often, male teachers are insensitive and may misbehave with girl students. Girls might have to suffer overt and tacit form of discrimination embedded in school environment. In case the girls are differently-abled, things change altogether as they might be deprived from education altogether. As far as opportunities are concerned, the government makes sure to provide Primary Schools and an Upper Primary School at $1 \mathrm{~km}$ and $3 \mathrm{~km}$ distance respectively. Also, separate toilets for girls are made mandatory under SSA. Recruitment of female staff is also essential for schools. There are entitlements for girl children to retain them to schools once they are enrolled.

\section{IMPACT}

The KGBVs have been able to provide not only education, fooding and lodging, stationary and toiletries, but also have opened a great vantage for the girls belonging to marginalized sections of the society. The training and education received at KGBVs enable them to be independent and strong enough to take their decisions in life, once they leave KGBV center. They receive life-long character building training. With trained and qualified staff to look after the girls, the KGBVs are achieving the goal they were set up with, i.e., of providing a free education along with vocational training, to girls from disadvantaged and marginalized sections of the society. The RTE Act attempts to bridge the gap between boys and girls on social and cultural level. To effectively implement the RTE Act, the Human Resource Development Ministry, Labor Ministry, Women and Child Development Ministry, Panchayati Raj Ministry and Rural Development Ministry have to work together. There should be an umbrella body that brings all these agencies together to work towards a common goal. The government must make every effort to become self-sufficient by using the education cess and other taxes to effectively implement the RTE Act. The RTE Act has been able to resolve some bottlenecks such as providing Special Residential and Non Residential Education Centres for Out of School Children (OoSC) and migrant children, providing toilet facility for girls and differently abled, availability and use of computers, etc. Once all these challenges are resolved, the implementation of RTE act will meet success and have a positive impact over the people. All sorts of socio-economic discrepancies should be removed to make this Act a success.

\section{DISCUSSION AND CONCLUSION}

Education also leads to girl child empowerment. It helps build their self- confidence, self-esteem; it transforms them from a docile person to an educated person who can handle the challenges of life and question inequalities. Gender-parity has been the overarching concern of the system on the whole. Through education, gender and social disadvantages can be resolved and equity can be achieved. Girls experience multiple forms of disadvantages. Curriculum, textbooks, and pedagogic practices need to capture the entire web of social 
and economic relations that determine an individual's location in the social reality and shape their lived experiences. There should be teachers' sensitization programmes to promote equitable learning opportunities. Interventions like gender training remain largely sporadic and need to be accelerated. Gender inclusive text books should be designed. It is high time to understand the structural and social barriers to girls' education and bring out systematic change. Scheduled Castes, Scheduled Tribes, Muslim girls are vulnerable, leading to them being Out of School Children (OoSC) and drop-outs. It is time to address the challenge. Measures include transport, escorts, counseling, helping them negotiate domestic work burdens, community support mechanisms. If the society wants to flourish then it will have to invest in a girl child's education [7]. There are educational disparities across the developing countries. When we educate a girl we empower her to have a say over the choices she has. Once educated, they can speak up for themselves, their rights, argue if wronged and demand justice. This would lead to making of a just society.

\section{ACKNOWLEDGMENT}

The author would like to thank the Center for Equity and Social Development, NIRD Hyderabad for providing an opportunity to work in the field of girl education.

\section{REFERENCES}

[1] Framework for Implementation Based on the Right of Children to Free and Compulsory Education Act, 2009, Ministry of Human Resource Development, Department of School Education and Literacy, Sarva Shiksha Abhiyan, 2011.

[2] K. Tomasevski, Human Rights and Poverty Reduction- Girls' Education through a Human Rights Lens: What Can be done Differently, What Can be Made Better, Odi Publications, 2005.

[3] A. Warner, A. Malhotra, and A. Mcgongale, "Girls' education, empowerment, and transitions to Adulthood: the case for a shared agenda," International Center for Research on Women, 2012.

[4] United Nations Girls' Education Initiative, 'Girls' too!' Education for All'. UNGEI Factsheet. (2006). [Online]. Available: http://www.ungei.org

[5] United Nations' Children's Fund, the State of World's Children 2007 : Women and Children-the Double Dividend of Gender Equality, UNICEF, NY, 2006, pp. 7.

[6] A Human Rights Based Approach to Education for All: a Framework for the Realization of Children's Right to Education and Rights within Education, UNICEF, NY, USA, 2007.

[7] Department for International Development, Girls Education: Towards a Better Future for All, DFID, 2005.

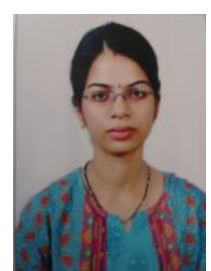

Sonal Mobar was born on October 2, 1981 in Lucknow Uttar Pradesh, India. She completed her studies from Lucknow University, pursuing PG in social anthropology and then doctorate in sociology from IIT Kanpur in 2012. She is currently working with Center for Equity and Social Development at National Institute of Rural Development, Hyderabad. She specializes in the field of rural development, IT in education, tribal studies, culture studies, social exclusion and stigma. She prefers to take an anthropological take at studying cultures and society. 